\title{
Factors Influencing ESL Primary School Teacher's Readiness in Implementing CEFR-aligned Curriculum
}

Nabilah Yasin ${ }^{1}$ and Hamidah Yamat*2

${ }^{1}$ Sekolah Kebangsaan Kota Masai 2,Malaysia

¿Universiti Kebangsaan Malaysia, Malaysia

Corresponding Author: Hamidah Yamat, E-mail: hamidah_yamat@ukm.edu.my

ARTICLE INFORMATION

Received: December 25, 2020

Accepted: February 12, 2021

Volume: 3

Issue: 2

DOI: $10.32996 /$ ijels.2021.3.2.6

\section{KEYWORDS}

CEFR-aligned curriculum, English as Secondary Language (ESL), teachers' readiness, factors, teaching and learning

\section{ABSTRACT}

English as a Second Language (ESL) teachers in Malaysia, as in many other countries, are anxious to exploit the potential of Common European Framework of Reference (CEFR) -aligned curriculum to enhance the teaching and learning process. Given the increasing pressure exerted by various stakeholders on language education, it is important to understand the underlying factors behind primary school teachers' readiness regarding CEFR-aligned curriculum. Even though there are studies conducted in local contexts, it is still very limited. This study seeks to find out the level of ESL primary teachers' readiness to implement CEFR-aligned curriculum. This study also investigates the factors that can influence teachers' readiness towards the implementation of CEFR-aligned curriculum. Data was collected via questionnaire survey from ESL primary school teachers in Pasir Gudang, Johor. The questionnaire data was analysed using descriptive statistics. The findings revealed that most of the teachers have high level of readiness in implementing CEFR-aligned curriculum. Several factors are also highlighted in this study. Teachers' training, competency, materials as well as school-based assessment are some of the main challenges identified in this study. In conclusion, the implementation of CEFR-aligned curriculum is seen as inevitable but more preparation and support should be provided by the ministry to ensure that teachers are fully prepared and familiar with the implementation of CEFR-aligned curriculum.

\section{Introduction}

The alignment of CEFR was seen as vital and significant as it would elevate the standard of Malaysia's syllabus and curricula to be at par with the international level because it conforms to the CEFR standard and requirement. Nevertheless, Aziz (2016) argued that the execution of CEFR will present multiple challenges for it to be adapted in the Malaysian education system. He mentioned that there are concerns that anything new could face the same outcome as previous well-intentioned programmes because of poor records in policy making. Based on a study conducted by Uri and Aziz (2018), despite the implementation plan of CEFR has entered its second phase, lack of readiness is still an issue among majority of the teachers although they have attended CEFR familiarization workshop and other CEFR-related in house-training. Hence, an extensive understanding of how CEFR-aligned syllabus, curricula and assessment are implemented by the teachers will provide the insights needed by other stakeholders to come up with better suggestions or recommendations that can further improve the effectiveness of CEFR.

Since CEFR-aligned syllabus and curricula were introduced in 2017, there has been lack of local studies that investigated the issues and challenges regarding CEFR in Malaysia. There are only a handful of studies that have been conducted locally and these studies are mostly small-scale studies with minimal impact to be used as a guide to help the authorities with the implementation of CEFR (Farehah, 2017) . Lo (2018) indicated that the role of a teacher is a crucial factor that can influence the curriculum change process. Hence, it is desirable to look at factors related to teacher before a curriculum innovation is implemented. Howard and Mozejko (2015) argued that for significant changes to happen in schools, teachers must be able to take risks and experiment with how they design different tasks and classroom interactions

K C AL-KINDI CENTER

$\mathbf{R}$ FOR RESEARCH AND DEVELOPMENT

Your gateway to world-class research

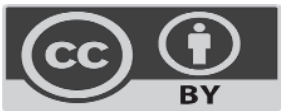

Published by Al-Kindi Center for Research and Development. Copyright (c) the author(s). This open access article is distributed under a Creative Commons Attribution (CC-BY) 4.0 license 
Therefore, it is deemed pertinent to understand the perspective of the teachers in Malaysia for their respective work. In this regard, the goal of this study is two-fold. First, the researchers focus to determine ESL primary school teachers' level of readiness on the implementation of CEFR-aligned curriculum. Second, the aim is to identify factors influencing teachers' readiness to implement CEFR, particularly based on their understanding of how CEFR-aligned curriculum is applied in the classroom. It is hoped that the results of this study could provide insights into the efficacy of CEFR-aligned syllabus and curricula towards English education in Malaysia. Apart from that, the results from this study could also provide more information and feedback to other future researchers in conducting their study. The main purpose of this study is to investigate level of ESL primary school teachers' readiness to implement CEFR-aligned curriculum.

\section{Literature Review \\ 2.1 CEFR in Malaysia}

By 2020, Malaysia has long aspired to be recognised internationally as an advanced high-income nation. Therefore, in order to change the aspiration into reality, a clearly defined agenda is needed. In order to improve employment prospects of young people; enable learners to participate fully in academic, professional and life; and take advantage of economic opportunities created by the formation of the Association of South East Asian Nations (ASEAN), the Ministry of Education (MOE) is driven to ensure quality in its teaching and learning in schools and higher learning institutions especially with regards to English. These aspirations have spurred the decision to benchmark the English language programme in Malaysia (Ahmad Afip et al., 2019).

Uri and Aziz, (2019) stated that it is still difficult to predict the impact of CEFR integration onto the education system due to the short period of time. However, past studies have revealed some expected or unexpected problems or issues that will affect the implementation of CEFR in Malaysia. Hence, it is imperative that a CEFR related study be conducted locally to address teachers' readiness in implementing CEFR in Malaysia. This study also seeks to discover the possible factors encountered by the teachers specifically in the process of adopting CEFR.

\subsection{Teachers' Readiness}

Based on a study conducted by Uri and Aziz (2018), ministry officials revealed that the biggest challenge faced by the ministry is the teachers. This is a major concern as teachers' lack of readiness could hamper the integration of CEFR-aligned curriculum. It needs to be acknowledged that teachers are at the centre of any innovations within national education systems and, therefore, studies involving the teachers and the relevant contexts should be carried out (Hayes, 2000).

Armenakis and Harris (2002) believes that change plays a crucial role as well as the ability possessed by the organization to implement the change successfully. They also added that the employee's role in the organization can be positively affected by applying the correct response to a situation and necessary support is provided by the organization involved.

In the context of this study, teachers play a central role in the implementation of a successful language policy or programme. Inandi and Gilic (2016) agreed with this idea as teachers are the most important shareholders of educational organizations. Hence, their thoughts and attitudes should be taken into consideration to ensure that the purposed change can be accomplished successfully.

\subsection{Factors' influencing teachers' readiness Lack of Training}

Uri and Aziz (2018) argued that despite the implementation plan of CEFR has entered its second phase, majority of the teachers are still not ready although they have attended CEFR familiarization workshop and other CEFR-related in house-training. Farehah (2017) indicated that this could be due to the lack of teachers' competency. Lack of qualified local English teachers who have the capability of adopting the CEFR-aligned curriculum and assessment system is still an issue in Malaysia. They analysed that most of them are still not sufficiently trained and in some cases, English teachers are selected to attend CEFR workshops because of their minimal pre-existing knowledge, not because they are specifically trained in Teaching English as Second Language (TESL). It was also revealed that 18 hours of training have been reduced to 6 hours by many schools due to time constraints, lack of qualified CEFR trainers and other contributing factors (Uri \& and Aziz, 2018). Kok and Azlina Abdul Aziz (2019) in their study examined that there is a serious need for more training among the teachers. Similarly, Aziz et al. (2018) in their study suggested that Ministry of Education (MOE) should provide more training as well as support as a form of initiative for the teachers to help each other on any platform, especially online. According to Crawford (1996), learning takes place in this zone whereby the people and social culture context bonded in shared experience. Aziz et al. (2018) further suggested that parts of the training need to be aligned with the local context so that teachers could find the input provided to be more relevant to them, and to the students specifically. 


\section{Teachers' Incompetency}

By 2025, the council needs to ensure that all English teachers would be at CEFR Level 1 because they are required to be one band higher than the students. This can be particularly challenging as according to a study done by Farehah (2017), it was found that only $25 \%$ of primary school teachers are qualified to teach English. Majority of the teachers fall under B1 and B2 categories. The Education Director-General issued a circular stating that English option teachers should have a minimum of CEFR, C1 level of qualification as 20,534 teachers had not yet taken any test to examine their level of English proficiency (Foley, 2019). This relatively poor performance of the teachers is a main concern as they are the main contributor to the successful implementation of any program.

\section{Lack of Localised Content and Learning Materials}

According to Ali et al. (2018), much of the criticism towards CEFR revolves around the neglect of localised contexts. It was revealed that the "English" way of setting in the textbook was seen as alien to both teachers and students thus created problems in the classroom (Ishak and Mohamad, 2018)

As stated by Aziz et al. (2018) previously, teachers were having difficulties in using the textbook due to the lack of localised content as well as suitable learning materials. They further mentioned that the arrangement of the textbook does not in sync with the curriculum and scheme of work. Hence, teachers were pressured to be flexible and must be ready to adapt to the needs and situation in the classroom, including during the planning of teaching and learning. However, in reality, teachers are not allowed to do so. Certain topics in the textbook are also considered to be unsuitable and insensitive to the local context. It was proposed that local context should be incorporated into textbooks as contextual learning facilitates more effective learning (Star, 2018). As a result, many teachers have to come up with their own initiatives and ideas such as finding materials via online, prepare their own materials, discussing and sharing resources with others (Kok and Azlina Abdul Aziz, 2019).

\section{School-Based Assessment}

There are several challenges that could hamper the successful implementation of school-based assessment. They are teachers' readiness due to limited understanding behind the implementation of school-based assessment, the additional burden to the teachers' workload, time constraints due to clerical work and large class size as well as the lack of supporting materials in implementing school-based assessment (Chin et al. 2019, Sidhu et al. 2018, Mohamed et al. 2018)

It is imperative that more attention should be given on the teachers as this new assessment system will require greater demand on teachers' role in assessing their students. This is aligned with Ong (2010) who argued that the success of the assessment system depends on the professional development of as well as the support provided to the teachers.

\section{Methodology}

This is a descriptive research which will determine the ESL primary school teachers' level of readiness and factors influencing the readiness regarding the implementation of CEFR-aligned curriculum. A quantitative-based study is conducted whereby the data are collected from previous questionnaires that have been adapted. A pilot test was carried out to ensure the reliability of the instrument. The questionnaire consisted of demographic details as well as information relating to need analysis in terms of level of readiness and factors influencing the readiness towards the implementation of CEFR-aligned curriculum. Opened-ended questions are used in this questionnaire as it would lead to a greater discovery and wide range of responses as compared to closed-ended questions (Uri and Aziz, 2018). Responses were recorded in the form of Likert scale, ranging from 1 (Strongly disagree), 2 (Disagree), 3(Not sure), 4(Agree) and 5(Strongly agree).

The respondents for this study consisted of 79 English Language primary school teachers who are currently teaching Year 1 to Year 5 in Pasir Gudang, Johor. The reason they were selected is because they have fulfilled the certain criteria that were established for this study, which are certified in-service English teachers and have at least one year of teaching experience. Aside from that, the reason Pasir Gudang was chosen is because this area has a diverse background of rural, sub-urban and urban areas which could provide more insights and understanding regarding teachers' readiness.

The findings from the study were analysed using percentage and mean count based on results from SPSS version 26 . In order to measure the level of readiness, mean scores were used. As for the factors influencing the level of readiness, a descriptive analysis was obtained by calculating the percentage. The results were then presented in the form of tables. 


\section{Findings}

Table 1 displays the respondent distribution by gender with 13 males and 66 females were involved in the study.

Table 1: Distribution of Respondents Frequency by Gender

\begin{tabular}{ccc}
\hline & Frequency & Percent (\%) \\
\hline Male & 13 & 16.5 \\
Female & 66 & 83.5 \\
Total & 79 & 100.0 \\
\hline
\end{tabular}

Table 2: Mean of Teachers' Level of Readiness in Implementing CEFR-aligned Curriculum

\begin{tabular}{clc}
\hline No. & \multicolumn{1}{c}{ Item } & Mean \\
\hline A1 & I know what CEFR-aligned curriculum is all about (history/objectives/plan) & 4.01 \\
A2 & I can confidently explain about CEFR-aligned curriculum to anyone & 3.80 \\
A3 & I believe that I can help my colleague to understand more about CEFR & 3.78 \\
A4 & CEFR-aligned curriculum is relevant to my profession & 4.06 \\
A5 & The CEFR-aligned curriculum helps me to plan lesson and set objectives & 3.97 \\
A6 & I am ready to conduct the assessment to evaluate the pupils' progress formatively & 3.91 \\
A7 & I am ready to use the CEFR-aligned textbook during teaching & 4.08 \\
A8 & My pupils respond positively during the teaching and learning session \\
A9 & The CEFR-aligned curriculum covers topics that are interesting and engaging to my & 3.85 \\
& $\begin{array}{l}\text { pupils } \\
\text { A10 }\end{array}$ & The language functions and uses from the CEFR-aligned curriculum are appropriate \\
& $\begin{array}{l}\text { and necessary for my pupils to learn } \\
\text { A11 }\end{array}$ & The CEFR-aligned curriculum supports me to teach all four language skills equally \\
& $\begin{array}{l}\text { (speaking, writing, listening, reading) } \\
\end{array}$ & 4.94 \\
\end{tabular}

Mean Average

3.95

Based on Table 2, the highest mean score was recorded by the statement related to the usage of CEFR-aligned textbook during teaching ( $m-4.08)$ which indicates teachers' preference to use CEFR-based materials. The relevancy of CEFR-aligned curriculum is also recognised by the teachers and this is clearly stated from a relatively high mean score $(m-4.06)$. On the other hand, the teachers did admit that CEFR-aligned curriculum supports them to teach all four language skills based on the mean score obtained ( $m-4.04)$. In regard to teachers' understanding of CEFR-aligned curriculum, it obtained mean score of 4.01 which is considered to be high. Meanwhile, the lowest mean score recorded is at 3.78 which is related to teachers' perception in assisting their colleagues to have better understanding regarding the CEFR. Nevertheless, it is still considered to be moderately high.

Table 3: Percentage of Teachers' Training

\begin{tabular}{|c|c|c|c|c|c|c|}
\hline Item & Statements & SD & D & $\mathbf{N}$ & A & SA \\
\hline B1 & $\begin{array}{l}\text { I received plenty of training on CEFR-aligned curriculum from } \\
\text { courses and trainings. }\end{array}$ & 1.3 & 12.7 & 26.6 & 45.6 & 13.9 \\
\hline B2 & $\begin{array}{l}\text { My supervisor and colleagues have helped me a lot in training } \\
\text { me to become a better practitioner of CEFR-aligned curriculum. }\end{array}$ & 0 & 11.04 & 25.3 & 49.4 & 13.9 \\
\hline B3 & $\begin{array}{l}\text { I am confident that training and courses can open new chances } \\
\text { in my career prospect. }\end{array}$ & 0 & 6.3 & 22.8 & 53.2 & 17.17 \\
\hline B4 & $\begin{array}{l}\text { The contents of the training are related to my profession as a } \\
\text { teacher. }\end{array}$ & 0 & 1.3 & 15.2 & 57.0 & 26.6 \\
\hline B5 & $\begin{array}{l}\text { Other teachers in my school also believe that they will gain } \\
\text { more values from training. }\end{array}$ & 0 & 1.3 & 24.1 & 53.2 & 21.5 \\
\hline B6 & $\begin{array}{l}\text { If given a choice, I would like to receive more training and } \\
\text { courses regarding CEFR-aligned curriculum. }\end{array}$ & 1.3 & 1.3 & 21.5 & 48.1 & 27.8 \\
\hline
\end{tabular}


B7 I know that I am responsible to increase my own skills and $\quad \begin{array}{llll}0 & 0 & 10.1 & 46.8\end{array}$ knowledge.

${ }^{*}$ Note: $(n=79), S D$ : strongly disagree, SA: strongly agree

Table 3 displays teachers' training as one of the factors influencing level of readiness in implementing CEFR-aligned curriculum. From the table, $57.0 \%$ of the respondents agreed that the contents of the training that they received are related to their profession. Nevertheless, it was recorded that less than half of the respondents agreed that they received plenty of training related to CEFR-aligned curriculum, as claimed by $45.6 \%$ of the respondents. Regarding teachers' preference towards the training, $48.1 \%$ of the respondents agreed to receive more training and courses in the future. When it comes to their professional development, $53.2 \%$ respondents were aware that training can open new chances in their career prospect.

Table 4: Percentage of Teachers' Competency

\begin{tabular}{|c|c|c|c|c|c|c|}
\hline Item & Statements & SD & D & $\mathbf{N}$ & A & SA \\
\hline C1 & $\begin{array}{l}\text { Result from the Competency Test (CPT/APTIS/CEFR } \\
\text { Readiness) mirrors my competency to teach English. }\end{array}$ & 2.5 & 6.3 & 27.8 & 40.5 & 22.8 \\
\hline C2 & $\begin{array}{l}\text { I believe I'm competent enough to implement CEFR- } \\
\text { aligned curriculum. }\end{array}$ & 0 & 3.8 & 22.8 & 50.6 & 22.8 \\
\hline C3 & $\begin{array}{l}\text { I believe the Competency Test is vital to test English } \\
\text { teachers' competency in their profession. }\end{array}$ & 1.3 & 6.3 & 27.8 & 38.0 & 26.6 \\
\hline C4 & $\begin{array}{l}\text { I believe there is the need to test teachers' competency } \\
\text { towards their profession, especially in English language. }\end{array}$ & 2.5 & 6.3 & 27.8 & 35.4 & 27.8 \\
\hline C5 & $\begin{array}{l}\text { I would like to undertake more tests to further improve my } \\
\text { potential as a competent English teacher. }\end{array}$ & 6.3 & 11.4 & 26.6 & 39.2 & 16.5 \\
\hline
\end{tabular}

Based on Table 4, item 2 records the highest percentage with $50.6 \%$ of respondents believed that they were competent to implement CEFR-aligned curriculum. The role of competency test is also recognized by the teachers as $40.5 \%$ agreed that the results from competency test do reflect their competency. Meanwhile, only $35.4 \%$ of respondent agreed over the need to test teachers' competency while $27.8 \%$ strongly agreed to this statement.

Table 5: Percentage of Content \& Learning Materials

\begin{tabular}{|c|c|c|c|c|c|c|}
\hline Item & Statements & SD & D & $\mathbf{N}$ & A & SA \\
\hline D1 & $\begin{array}{l}\text { I prefer the usage of imported textbooks over localized } \\
\text { textbooks }\end{array}$ & 10.0 & 21.5 & 29.1 & 20.3 & 19.0 \\
\hline D2 & $\begin{array}{l}\text { Pupils are more interested to learn from the textbook compared } \\
\text { to other materials }\end{array}$ & 0 & 12.7 & 35.4 & 38.0 & 13.9 \\
\hline D3 & $\begin{array}{l}\text { Content from the textbook is relevant to the curriculum and } \\
\text { scheme of work. }\end{array}$ & 2.5 & 6.3 & 24.1 & 43.0 & 24.1 \\
\hline D4 & $\begin{array}{l}\text { I believe the content from the textbooks help pupils to relate } \\
\text { with their everyday lives. }\end{array}$ & 3.8 & 15.2 & 19.0 & 44.3 & 17.7 \\
\hline D5 & $\begin{array}{l}\text { I believe that the materials provided by the school are sufficient } \\
\text { to utilize the materials for me to teach CEFR-aligned curriculum. }\end{array}$ & 3.8 & 7.6 & 30.4 & 44.3 & 13.9 \\
\hline \multirow[t]{2}{*}{ D6 } & $\begin{array}{l}\text { I have to make some adaptation to the materials to help pupils } \\
\text { understand better. }\end{array}$ & 0 & 1.3 & 11.4 & 63.3 & 24.1 \\
\hline & ${ }^{*}$ Note: $(n=79)$, SD: strongly disagree, SA: strongly agree & & & & & \\
\hline
\end{tabular}

Based on Table 5, the highest percentage was recorded by the statement related to the need for materials' adaptation (63.3\%), and thus, indicating teachers' preference to adapt the materials. For the usage of imported textbooks, $29.1 \%$ of the respondents were unsure with this statement. This implies teachers' preference to use localized textbooks over the imported ones. This is in contrast with $38.0 \%$ of the respondents who claimed that pupils preferred to learn from the textbook compared to other 
materials. Results also revealed that $44.3 \%$ of respondents believed that the contents from the textbook were relatable to pupils' experience. In regard to sufficiency of the materials, $44.3 \%$ respondents agreed that the materials provided were enough.

Table 6: Percentage of School-based Assessment

\begin{tabular}{|c|c|c|c|c|c|c|}
\hline Item & Statements & SD & D & $\mathbf{N}$ & A & SA \\
\hline E1 & $\begin{array}{l}\text { I believe that school-based assessment is better than examination- } \\
\text { oriented assessment for the students. }\end{array}$ & 2.5 & 16.5 & 26.6 & 30.4 & 24.1 \\
\hline E2 & $\begin{array}{l}\text { I believe that school-based assessment puts less pressure on the } \\
\text { students and teachers. }\end{array}$ & 3.8 & 19.0 & 26.6 & 29.1 & 21.5 \\
\hline E3 & $\begin{array}{l}\text { It is hard for me to effectively evaluate my students due to the time } \\
\text { constraints. }\end{array}$ & 6.3 & 2.5 & 12.7 & 46.8 & 31.6 \\
\hline E4 & $\begin{array}{l}\text { It is challenging for me to assess my students due to the large class } \\
\text { enrolments. }\end{array}$ & 5.1 & 3.8 & 11.4 & 38.0 & 41.8 \\
\hline E5 & $\begin{array}{l}\text { It is challenging for me to assess my students due to the heavy } \\
\text { workload at school. }\end{array}$ & 1.3 & 3.8 & 12.7 & 35.4 & 46.8 \\
\hline E6 & $\begin{array}{l}\text { I believe there is a need to modify/adapt school-based assessment } \\
\text { to improve its reliability effectively. }\end{array}$ & 0 & 2.5 & 15.2 & 44.3 & 38.0 \\
\hline
\end{tabular}

Table 6 indicates the percentage of school-based assessment as a contributing factor influencing teachers' level of readiness. Based on the table, $30.4 \%$ of the respondents preferred school-based assessment over examination-oriented assessment. Over $44.3 \%$ of respondents agreed that they need to modify/adapt school-based assessment. The three remaining items revealed the major challenges that affect the teachers in carrying out the assessment. For instance, $46.8 \%$ of the respondents stated time constraints as one of the challenges. Meanwhile, $46.8 \%$ and $41.8 \%$ of respondents strongly agreed that heavy workload and large class enrolments affect them to assess their pupils effectively.

\section{Discussion}

In order to determine the readiness level, teachers need to report the perceptions based on the 11 levels of readiness related items with a five-point Likert scale with 1 being "strongly disagree" and 5 being "strongly agree". Konting's (1990) interpretations of score and level was used to interpret the results (see Table 7). It was defined that the mean score of 1.00 to 2.33 is interpreted as low level of readiness while 2.34 to 3.66 is interpreted as moderate level of readiness. On the other hand, mean score of 3.67 to 5.00 need to be achieved to obtain the high level of readiness among the respondents. Similar interpretation scale was also adopted in the past studies by Osman and Hamzah (2017) and Muhammad et al. (2017)

Table 7: Interpretations of Score and Level

\begin{tabular}{cc}
\hline Score & Level \\
\hline $1.00-2.33$ & Low \\
\hline $2.34-3.66$ & Moderate \\
\hline $3.67-5.00$ & High
\end{tabular}

Source: Konting (1990)

Based on the overall average outcome for each construct in Table 7, it is evident that the mean average for teachers' level of readiness in the implementation of CEFR-aligned curriculum is at 3.95 which is within the range of 3.00 (neutral) to 4.00 (agree) of the Likert scale. According to the mean interpretation by Konting (1990), 3.95 falls within the category of high level. This shows that most of the respondents possess high level of readiness towards the implementation of CEFR-aligned curriculum. This is in contrast with the research finding from Lo (2018) which indicates high levels of concern and anxiety towards the implementation of CEFR-aligned curriculum. Thus, this signifies the level of teachers' readiness has increased over the years.

In respect of teachers' training, the outcome of the research showed that majority of the teachers had received training or courses provided by the MOE. It is also clear that teachers are being given assistance and help from their supervisors or colleagues at school. This is in line with Crawford (1996) which states that learning takes place in this zone whereby the people 
and social culture context bonded in shared experience. Hence, interaction between the teachers under proper supervision and peer cooperation will further improve their potential in becoming better ESL teachers. In addition to that, it was also discovered that teachers' awareness regarding the importance of training is high as most of them are aware of the potential of training and courses towards their career prospect.

Despite that, findings of this research indicated a serious need for more training as majority of the teachers expressed the need for more training. This could be interpreted that the current training received is inadequate for teachers' professional development. This is in line with findings from a previous study by Farehah (2017) which argued that most of the teachers were still not adequately trained. This is also in accordance with a study by Kok and Azlina Abdul Aziz (2019) who argued that teachers require more courses and training as the current training provided is insufficient to cope with the CEFR-aligned curriculum.

As indicated by Farehah (2017), lack of teachers' competency could lead to teachers' lack of readiness in implementing CEFRaligned curriculum. Findings from this study showed that majority of the teachers did not agree with this statement as they believed that they were competent enough in regards to the results from the competency test. This indicates that majority of the teachers were satisfied with the results pertaining to the competency test. This is contrary to the finding from Farehah (2017) where it was found that majority of the ESL teachers are not proficient to teach English. However, it should be highlighted that a small majority of teachers felt the need for more competency test in the future while some of them were not sure with this statement. It is important that teachers need to be competent in their respective field. But care must be taken as not to put the teachers in more pressure than it is necessary.

In respect to content and learning materials, it was evident that a large number of the respondents from the survey had mixed views regarding the usage of imported textbooks over localized textbooks. It was revealed that most of them were unsure with this statement. Nevertheless, data also showed that majority of the teachers opined that contents of the textbook were relevant with the curriculum and pupils' environment. The findings contradict the findings from previous studies conducted by Kok and Azlina Abdul Aziz (2019), Aziz et al. (2018), Uri and Aziz (2019) which highlighted the issues of foreign cultural references from the textbook.

However, it should also be highlighted that majority of the teachers expressed the need for adaptation to be made accordingly. This implies that teachers have to take additional measures to adapt the content of the textbook in order to suit the pupils' environment and needs. This correlates with a previous study by Alih et al. (2020) which states that contextualization is the major concern related to textbook prescribed by the ministry. Due to the internalization of the contents, students find it hard for them to comprehend the contents especially those with low English proficiency. Kok and Azlina Abdul Aziz (2019) suggested that a locally based textbook could be developed to suit with the students' socio-cultural experience. Therefore, a review on the content of the textbook should be taken into consideration to ensure a more effective learning to take place.

As for the assessment method is concerned, the findings showed that there were three major challenges and issues highlighted by the teachers. These issues were time constraints, large class enrolments and heavy workload at school. These findings coincide to the discovery made by Sidhu et al. (2018) which attributed time constraints, classroom enrolment and heavy workload as main challenges that can hamper the effectiveness of school-based assessment. Chin et al. (2019) and Mohamed et al. (2018) also concurred with the findings mentioned above. In order to solve these issues, MOE or administrators are urged to provide more time, lessen the number of pupils in each class and reduce teachers' workload. More priority should be allocated on the teachers' and pupils' needs and wellbeing instead of focusing on other less significant field like clerical work.

\section{Conclusion}

This study aimed to examine the level of teachers' readiness and factors that can influence the teachers' readiness in implementing CEFR-aligned curriculum. Arising from the findings of this study, one major conclusion that could be drawn is the CEFR-aligned curriculum is moving in a positive direction and has gained wide support from the teachers. However, the present study is focused on a small sample of teacher corpus that is particularly gathered for the research. Hence, the results might not be appropriate to be applied and generalised on bigger population. Nevertheless, the findings revealed several factors or issues raised by the teachers during the implementation of CEFR-aligned curriculum. The evidence from the study suggests the needs of improvement and adaptation that could be raised for the future research. Further studies could also be conducted to identify the level of teachers' readiness among secondary schools since this research only applies to primary school ESL teachers.

\section{References}

[1] Ahmad Afip, L., Hamid, M. O., \& Renshaw, P. (2019). Common European framework of reference for languages (CEFR): insights into global policy borrowing in Malaysian higher education. Globalisation, Societies and Education, 17(3), 378-393.

[2] Ali, Z. M., Ali, F., Radzuan, N. M., Alwi, N. N. M., Abu, N. L., \& Kassim, Z.(2018).Contextualising the CefR: the Universiti Malaysia Pahang English language proficiency writing test. 
[3] Alih, N. A C., Yusoff, M. A. M., \& Abdul, A.H. (2020). "Teachers' Classroom." Educational Research (IJMCER) 2.5 (2020): 126-134.

[4] Armenakis, A. A., Harris, S. G., \& Mossholder, K. W. (1993). Creating readiness for 703.

Aziz, A. H. A. A., Ab Rashid, R., \& Zainudin, W. Z. W. (2018). The enactment of the Malaysian common European framework of reference (CEFR): National master trainer's reflection. Indonesian Journal of Applied Linguistics, 8(2), 409-417.

[5] Aziz, H. (2016). Raising English proficiency. New Straits Times. 28 Sept: 1

[6] Chin, H., Thien, L. M., \& Chiew, C. M. (2019). The reforms of national assessments in Malaysian Education System. Journal of Nusantara Studies (JONUS), 4(1), 93-111.

[7] Crawford, K. (1996). Vygotskian approaches to human development in the information era. Educational Studies in Mathematics, (31), 43-62. http://dx.doi.org/10.1007/BF00143926

[8] Foley, J. (2019). Issues on the initial impact of CEFR in Thailand and the region. Indonesian Journal of Applied Linguistics, 9(2), 359370.

[9] Hayes, D. (2000). Cascade training and teachers' professional development. ELT journal, 54(2), 135-145.

[10] Howard, S. K., \& Mozejko, A. (2015). Teachers: technology, change anresistance. Teaching and digital technologies: Big issues and critical questions, 307-317.

[11] Inandi, Y., \& Giliç, F. (2016). Relationship of Teachers' Readiness for Change with Their Participation in Decision Making and School Culture. Educational Research and Reviews, 11(8), 823-833.

[12] Ishak, W. I. W., \& Mohamad, M. (2018). The Implementation of Common European Framework of References (CEFR): What Are the Effects Towards LINUS Students' Achievements?. Creative Education, 9(16), 2714-2731.

[13] Kok, N. M. (2019). English language teachers' perceptions on theimplementation of CEFR-aligned curriculum among primary schools in Malaysia.

[14] Konting, M. M. (1990). Kaedah penyelidikan pendidikan. Dewan Bahasa dan Pustaka.

[15] Lan Ong, S. (2010). Assessment profile of Malaysia: high-stakes external examinations dominate. Assessment in Education: Principles, Policy \& Practice, 17(1), 91-103.

[16] Lo, Y. Y. (2018). English teachers'concern on Common European Framework of Reference for languages (CEFR): an application of CBAM. JuKu: Jurnal Kurikulum \& Pengajaran Asia Pasifik, 6(1), 46-58.

[17] Mohamed, M., \& Abd Aziz, M. S. (2018). Juxtaposing the primary school assessment concepts and practices in Singapore and Malaysia. International Journal of Engineering \& Technology, 7(3.21), 552-556.

[18] Muhamad, S. H., Nuwairi, N., \& Rani, Z. A. (2017). Student readines towards different options of blended learning in English literature classrooms at tertiary level: A pilot study.

[19] Osman, N., \& Hamzah, M. I. (2017). Student readiness in learning Arabic language based on blended learning. International Journal of Applied Linguistics and English Literature, 6(5), 83-89.

[20] Sidhu, G. K., Kaur, S., \& Chi, L. J. (2018). CEFR-aligned school-based assessment in the Malaysian primary ESL classroom. Indonesian Journal of Applied Linguistics, 8(2),452-463.

[21] Star, T. (2018, February). Let's have our own textbooks. The Star Education. Kuala Lumpur. Retrieved from https://www.thestar.com.my/news/education/2018/02/04/lets-have-our- own-textbooks

[22] Uri, M. (2017, December). NF \& Sallehhudin Abd Aziz, M.(2017). CEFR in Malaysia: Current issues and challenges in the implementation of the framework. In The $3^{\text {rd }}$

International Conference on Language Testing and Assessment and 5th British Council New Directions in Language Assessment Conference (pp. 2-3).

[23] Uri, N. F. M., \& Abd Aziz, M. S. (2018). Implementation of CEFR in Malaysia: Teachers' awareness and the Challenges. 3L: Language, Linguistics, Literature ${ }^{\circledR}, 24(3)$.

[24] Uri, N. F. M., \& Abd Aziz, M. S. (2019). Teachers' evaluation of the suitability of reading syllabus specifications to the CEFR. Journal of English Language Teaching and Applied Linguistics, 1(1), 32-44. 